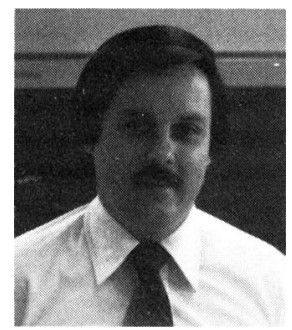

Kenneth C. Crawford is now Deputy Meteorologist-in-Charge of the New Orleans Area Forecast and Hurricane Warning Office. Crawford joined the staff of the National Severe Storms Laboratory in 1968 , spending almost five years there as a research meteorologist in the early phases of the Doppler Radar Program. He first came to the New Orleans NWS office in 1972 and, after a brief tour in the NWS Southern Region Scientific Services Division, he became Marine Special Program Meteorologist in New Orleans. Most recently he spent two years as Lead Forecaster at the NWS forecast office in Ft. Worth, Tex. Crawford, who holds the Ph.D. (1977) from the University of Oklahoma, is currently Chairman of the AMS New Orleans Chapter.

David M. Feit has received a two-year appointment as Scientific Officer in the Ocean Affairs Division of the World Meteorological Organization, Geneva. Since 1977 Feit had been Marine FocalPoint Meteorologist for the NWS forecast office in Boston, Mass. Before that he was a research meteorologist with the Techniques Development Laboratory, Systems Development Office, NWS. Feit assumed his new position in July. During 1980-81, Feit served on the AMS Admissions Committee.

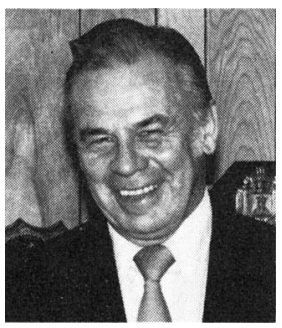

Robert W. Fett, head of the tactical applications department of the Naval Environmental Prediction Research Facility (NEPRF) in Monterey, Calif., has received the Rear Admiral William S. Parsons Award for Scientific and Technical Progress, a national honor given annually by the Navy League of the United States. Fett's award for science recognized his research and development achievements in the field of analysis and applications of satellite imagery, work that has led to publication of a series of Navy Tactical Applications Guides widely used by forecasters who employ satellite data to analyze and predict maritime weather phenomena and events. A retired U.S. Air Force Lieutenant Colonel, Fett was the 1965 recipient of the Air Weather Service's Merewether Award for that year's "most valuable contribution to military meteorology." He has been with NEPRF since 1972.

Wilbur L. Figgins is now Lead Forecaster at the NWS forecast office in Salt Lake City, Utah. He had been a forecaster at that same office.

${ }^{1}$ Members are encouraged to submit news items on themselves or colleagues that will be of interest to fellow members. Copy should be typed double-spaced; photos accompanying news items should be black and white.-News Ed.
Phillip H. Gillaspy has received the Ph.D. in physics from the University of Nevada-Reno. He also has been appointed a Visiting Scientist in the Atmospheric Sciences Division of the National Aeronautics and Space Administration's Marshall Space Flight Center, where he will help develop satellite-based instrumentation to study lightning. Gillaspy holds the B.A. and the M.A. in meteorology from San Jose State University.

Paul H. Gross, a student in the Department of Atmospheric and Oceanic Sciences at the University of Michigan, has been spending this summer as an intern at WDIV-TV in Detroit, Mich. Gross is working in the station's "weathercenter," where his specific duties include analyzing teletypewriter and surface map data and making preliminary forecasts.

NWS Intern Arthur A. Horton recently received an NWS Special Merit Award. Horton is assigned to the Portland, Oreg., forecast office. He holds the B.S. (1977) in meteorology from Oregon State University.

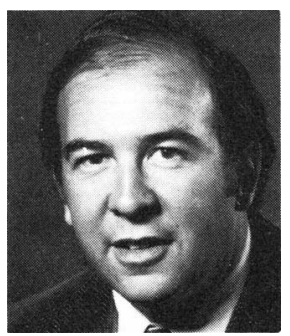

Garry Hunt, Head of the Laboratory for Planetary Atmospheres, University College London, has been awarded the degree of Doctor of Science by the University of London. Hunt also has been appointed Rouse Ball Lecturer at the University of Cambridge and will deliver the Scott Lectures during 1981.

Claire Jensen has been elected President of the Arizona Emergency Services Association (AESA), a state-wide group interested in the prevention or mitigation of disasters. Members are from federal, state, county, and local governments, as well as the private sector. Jensen, Meteorologist-in-Charge of the NWS office in Phoenix, Ariz., also has been Vice-President of AESA.

Max A. Kohler has been elected to membership in the National Academy of Engineering. His contributions have been honored on several previous occasions as well: with the Department of Commerce Meritorious Award, Gold Medal, and Distinguished Service Award; and with the Washington Academy of Science Award in Engineering. He has been an AMS Councilor (1972-75) and served on the Society's Planning Commission (1974-76). In 1975 he was honored by AMS as the Robert E. Horton Lecturer in Hydrology, and he has been elected a Fellow of both the American Geophysical Union and the American Society of Civil Engineers. 
Paul H. LeBlond and Lawrence A. Mysak recently received the Canadian Meteorological and Oceanographic Society's (CMOS) President's Prize for 1980 "in recognition of their outstanding ocean research, specifically their extensive and original studies of waves, as presented at CMOS meetings and published in their recent book Waves in the Ocean." The award was presented at the 1981 CMOS Annual General Meeting in Saskatoon, Sask. LeBlond is a Professor of Oceanography and Physics and Mysak is a Professor of Mathematics and Oceanography, both at the University of British Columbia, Vancouver, B.C.

Harold S. McCrabb has received a Certificate of Commendation from the City of Ft. Worth, Tex., "for demonstrating outstanding leadership, cooperation, contribution of time and effort to train spotters and help[ing] furnish the Metroplex outstanding severe weather warning service." McCrabb is Meteorologist-in-Charge of the NWS forecast office in Ft. Worth. He received his meteorological training at the University of Chicago and the University of California-Los Angeles, and also holds the M.A. in mathematics.

Charles E. Orwig has received a Department of Commerce Bronze Medal, given for his superior federal service in the field of hydrology, particularly in flood and water supply forecasting. Orwig is Deputy Hydrologist-in-Charge of the River Forecast Center in Portland, Oregon. He was presented his award at a meeting of the AMS Oregon Chapter.

Glenn L. Rasch, Operation Meteorologist at the NWS forecast office in Salt Lake City, recently received an NWS Outstanding Performance Rating. He holds the B.S. (1967) and the M.S. (1973) in meteorology from the University of Utah, Salt Lake City.

Robert $O$. Reid has headed the Department of Oceanography at Texas A\&M University since January. Reid has been a university faculty member in the oceanography department since 1951 and a Distinguished Professor of Oceanography since 1978. The university also awarded him a Faculty Distinguished Achievement Award in 1960. Reid was Editor of the Journal of Physical OCEANOGRAPHY from its beginning in 1971 until 1979. AMS recognized his skillful editorial and scientific work on the journal with a Special Award in 1975.

Robert J. Serafin recently was appointed Director of the Atmospheric Technology Division (ATD) of the National Center for Atmospheric Research (NCAR) in Boulder, Colo. The ATD operates NCAR's radar facilities in Boulder, research aircraft at Jefferson County Airport, and the scientific ballooning facility in Palestine, Tex. ATD's current efforts include developing new scientific instruments for probing and revealing properties of the atmosphere and its weather. For the past seven years, Serafin was manager of NCAR's Field Observing Facility. Prior to joining NCAR in 1973, he was with the Illinois Institute of Technology's Research Institute, where he held several positions in research engineering. Serafin, who holds the Ph.D. (1972) from the Illinois Institute of Technology, is an Associate Editor of the JOURNAL OF APPLIED Meteorology and a member of the Society's Committee on Radar Meteorology.

\section{ANTENNA ASSEMBLY} RD-65

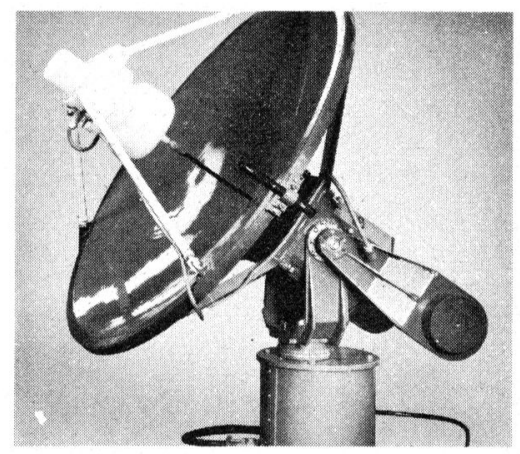

Four "Weathersonde RD-65" Radiosonde Systems complete with Recorders, Spares, Subassemblies, Plotting Boards and other accessories.

Available from: Defense Division of Brunswick Corporation, Costa Mesa, CA.

Contact: Wayne MacCartney (714) 546-8030, Ext 6416

Richard W. Schwerdt is now the Warning and Preparedness Meteorologist at the Washington, D.C., NWS forecast office. His area of responsibility includes Virginia, West Virginia, Maryland, Delaware, and the District of Columbia. Schwerdt served at the National Climatic Center, Asheville, N.C., during 1965-68 and was Editor of Mariners Weather Log from 1968 to 1972. He holds the M.S. from Florida State University.

Stanley L. Wasserman has been selected as Chief of the NWS Eastern Region Headquarters (ERH) Meteorological Services Division. He was Chief of the ERH Data Acquisition Division for the past five years, and, prior to that, he was a Satellite Meteorology and Techniques Development Meteorologist in the ERH Scientific Services Division. Wasserman, along with others, was instrumental in introducing both satellite meteorology to the NWS Eastern Region and the use of numerical model output for point locations to regional field forecasters, and most recently, in bringing color digital radar remote information into many regional field stations.

\section{retirements}

Raymond C. Crooks retired in January 1981 after nearly 39 years of federal service. Crooks entered the weather service as an analyst at 


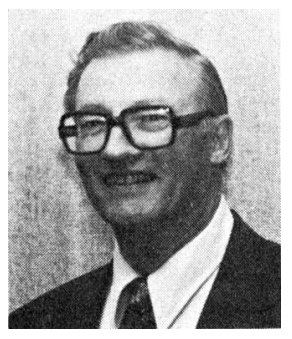

the National Meteorological Center in Washington, D.C., in 1942. Subsequent assignments included aviation forecaster at Dayton, Ohio, and Seattle, Wash.; research analyst at New York University; civilian technician with the U.S. Navy Air Squadron at Honolulu, Hawaii; international aviation forecaster at Limerick, Ireland; and guidance forecaster, Great Falls, Mont., and San Francisco, Calif. He came to Oklahoma City, Okla,, in 1965 as Meteorologist-in-Charge of the weather service forecast office there, holding that position until his retirement. He also served as Chairman of the Central Oklahoma Chapter during 1967-68. Crooks earned the B.S. in meteorology from the University of Chicago, where he also pursued graduate studies. Crooks' retirement plans include spending more time with his gardening and stamp collecting interests, traveling, and doing private meteorological consulting work. He and his wife, Lois, continue to reside in Oklahoma City.

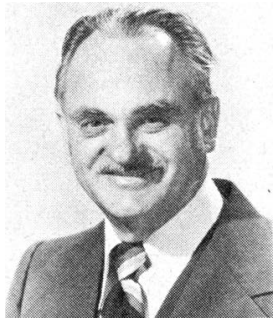

Hubert C. Keith retired in February 1981 after 37 years of federal service, including four years in the military. He entered the U.S. Weather Bureau in 1948 and served in Baltimore, Md., and at the National Meteorological Center prior to transferring to the Boise, Idaho, forecast office as Principal Assistant in 1970. He was appointed Meteorologist-in-Charge at Boise in 1978, holding that position until his retirement. He also retired from the U.S. Air Force Reserve with the rank of colonel in June 1980. Keith earned the A.B. from Washington University, St. Louis, Mo., and completed graduate studies in mathematics at The Johns Hopkins University in Baltimore. He was Treasurer of the AMS Chapter in Baltimore, Md., during 1954-55. Keith currently serves as a meteorological consultant to the Idaho Public Utilities Commission, advising on solar radiation zones for the state and a projected nongovernmental network for solar radiation measurements. He and his wife, Billie, continue to live at 8350 Crestwood Dr., Boise, Idaho 83704. announcements (continued from page 1223)

\section{Swedish Committee for Polar Research}

The Royal Swedish Academy of Sciences has established, under its auspices, the Swedish Committee for Polar Research. The Committee aims to promote Swedish polar research and to stimulate interest and knowledge about the polar regions. The committee also will serve as a Swedish focal point for international scientific cooperation concerning polar research and will act as a liaison organization to Comité Arctique in Monaco.

Members of the committee are: Ragnar Edenman, Chairman; Bert Bolin, Department of Meteorology, University of Stockholm; Kurt Boström, Department of Geology, University of Stockholm; Erik Bylund, Department of Human Geography, University of Umeå; Hans Dahlin, National Marine Resources Commission; David Dyrssen, Department of Analytical and Marine Chemistry, University of Göteborg and Chalmers University of Technology; Bengt Hultqvist, Kiruna Geophysical Institute; Bo Johnson, Ministry of Foreign Affairs; Anders Karlqvist, Swedish Council for Planning and Coordination of Research; Valter Schytt, Department of Physical Geography (Glaciology), University of Stockholm; Mats Sonesson, Abisko Scientific Research Station, The Royal Swedish Academy of Sciences; and Jarl-Ove Strömberg, Kristinebergs Marine Biological Station, The Royal Swedish Academy of Sciences.

Information about the new committee may be obtained from: Swedish Committee for Polar Research, The Royal Swedish Academy of Sciences, Box 50005, S-104 05 Stockholm, Sweden (Telex: 17073 royacad ś).

\section{Mississippi Sound hydrographic and climatic atlas}

Mississippi Sound: A Hydrographic and Climatic Atlas has been completed recently by Charles K. Eleuterius and Sheree Beaugez of the Gulf Coast Research Laboratory staff. The atlas is a synthesis of available hydrographic and climatic data/information for Mississippi Sound in the northern Gulf of Mexico.

Hydrographic data from more than three years have been processed in the atlas by seasons, with the minimum, maximum, mean, median, and a coefficient of variability computed for water temperature, salinity, density, $\mathrm{pH}$, and dissolved oxygen for surface waters and at depths of $1.5 \mathrm{~m}, 3 \mathrm{~m}$, and near bottom. These same statistical parameters also have been determined for nitrite-nitrogen, nitratenitrogen, orthophosphate, and total phosphate for surface waters. Isopleth charts have been made using computer mapping programs to depict each hydrographic variable for each statistical measure. Information on tides, hurricanes, bathymetry, wave climate, weather patterns, river flow, air temperature, photic period, monthly wind speed and direction, and cross-sectional areas of island passes have been presented graphically. A total of 523 illustrations appear in the 145-page atlas. In addition to explaining essentials regarding the information displayed, the text provides supplemental information on the dynamic nature of Mississippi Sound.

Because limited production necessarily will restrict distribution of the atlas, those institutions or individuals with a demonstrable need for the atlas should contact: Ms. Dianne Jones, MississippiAlabama Sea Grant Consortium, East Beach, Ocean Springs, Miss. 39564. 